\title{
Prognostic value of MET protein overexpression and gene amplification in locoregionally advanced nasopharyngeal carcinoma
}

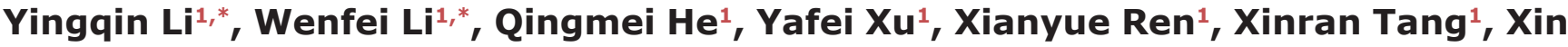 \\ Wen $^{1}$, Xiaojing Yang ${ }^{1}$, Ying Sun ${ }^{1}$, Jing Zeng ${ }^{2}$, Jingping Yun ${ }^{2}$, Na Liu ${ }^{1}$, Jun Ma ${ }^{1}$ \\ 'Sun Yat-senUniversityCancerCenter;StateKeyLaboratoryofOncologyinSouthChina, CollaborativeInnovationCenter \\ of Cancer Medicine, Guangzhou, China \\ ${ }^{2}$ Department of Pathology, State Key Laboratory of Oncology in South China, Sun Yat-sen University Cancer Center, \\ Guangzhou, China \\ *These authors contributed equally to this work
}

Correspondence to:

Na Liu, e-mail: liun1@sysucc.org.cn

Jun Ma, e-mail: majun2@mail.sysu.edu.cn

Keywords: MET overexpression, MET amplification, prognosis, locoregionally advanced nasopharyngeal carcinoma

Received: February 27, 2015

Accepted: April 08, 2015

Published: April 20, 2015

\section{ABSTRACT}

This study assessed the incidence and prognostic value of MET protein overexpression and gene amplification in locoregionally advanced nasopharyngeal carcinoma (NPC). Specimens from 376 consecutive patients with locoregionally advanced NPC were subjected to immunohistochemistry to analyze MET protein expression and fluorescence in situ hybridization to assess MET amplification status. In total, 139/376 (37.0\%) patients had MET protein overexpression; of whom, 7/139 (5.0\%) had MET amplification. MET overexpression was significantly associated with locoregional failure $(P=0.009)$, distant metastasis $(P=0.006)$ and death $(P<0.001)$; MET amplification was significantly associated with death $(P=0.021)$. A positive correlation was observed between MET copy number status and MET protein expression $(r=0.629, P<0.001)$. Multivariate analysis demonstrated MET overexpression was an independent prognostic factor for overall survival (OS; HR, 1.99; 95\% CI, 1.38-2.87; $P<0.001$ ) and disease-free survival (DFS; HR, 1.85; 95\% CI, 1.33-2.57; $P<0.001$ ), and MET amplification was independently associated with poorer OS (HR, 4.24; $95 \% \mathrm{CI}, 1.78-10.08$; $P<0.001)$ and DFS (HR, 5.44; 95\% CI, 2.44-12.09; $P<0.001)$. In conclusion, MET protein overexpression and gene amplification are independent prognostic factors for OS and DFS in locoregionally advanced nasopharyngeal carcinoma, and may provide therapeutic biomarkers to identify patients in whom MET inhibitors may be beneficial.

\section{INTRODUCTION}

Nasopharyngeal carcinoma (NPC) is one of the most common head and neck malignancies in Southern China, where the rates vary from 30 to 80 cases per 100,000 $[1,2]$. Unfortunately, about $80 \%$ of patients with NPC are diagnosed with advanced disease at their first visit, due to the deep anatomical position and non-specific symptoms of this tumor type [3]. Intensity-modulated radiotherapy combined with platinum-based chemoradiotherapy is the standard treatment for locoregionally advanced NPC $[4,5]$. Although local and regional control rates have improved, more than $30 \%$ of patients still develop recurrence and distant metastasis $[6,7]$. These challenges urgently require the development of novel therapeutic strategies to improve the clinical outcome of patients with locoregionally advanced NPC. Recently, a new generation of molecular targeted drugs has been added to traditional chemotherapy and demonstrated therapeutic efficacy [8, 9]. Therefore, identification of novel molecular aberrations in specific subgroups of patients may facilitate the development of other targeted therapies and guide individualized treatment protocols for patients with NPC. 
The MET proto-oncogene encodes the receptor tyrosine kinase MET, which is activated by its ligand, hepatocyte growth factor (HGF) $[10,11]$. Binding of HGF to MET results in phosphorylation of the receptor tyrosine kinase domain, and in turn mediates downstream signaling via the PI3K/AKT, STAT3, RAS-RAC/RHO and MAPK pathways [12, 13]. Normal MET signaling is required for embryogenesis, cell growth, cell differentiation and angiogenesis $[14,15]$. Constitutive activation of the MET pathway has been reported in various types of cancer, and promotes tumor cell proliferation, motility, invasion and metastasis [16, 17]. Aberrant MET activation can occur via multiple mechanisms, including gene amplification and mutation, dysregulation of microRNAs that target MET, paracrine or autocrine activation via HGF, and protein overexpression $[18,19]$. Recent studies demonstrated MET overexpression and MET amplification were associated with poorer clinical outcomes in non-small cell lung cancer and gastric cancer [20-22]. On this basis, MET has emerged as a potential target for anticancer therapy.

Currently, a number of MET inhibitors have been developed and are in clinical trials at different phases [23-26]. The preliminary results of these trials have demonstrated MET inhibitors have variable benefits in unselected patient cohorts, which suggests the need for a selective biomarker to indicate subgroups of patients that may potentially obtain more benefit from MET inhibitors. Preclinical studies indicated MET amplification can be used to identify subgroups of patients with gastric cancer who are sensitive to MET inhibitors [27]. However, the frequency and prognostic value of MET overexpression in NPC remains controversial due to the use of varied detection methods, cutoff criteria and populations in different studies [28-30]. More importantly, the frequency of MET amplification in NPC has not yet been determined.

Therefore, in this study, we aimed to evaluate the frequency of MET protein overexpression in patients with locoregionally advanced NPC, and the incidence of MET amplification in patients overexpressing MET. In addition, we analyzed the association with clinicopathological features, as well as the prognostic value of MET overexpression and $M E T$ amplification to assess the value of MET as a potential therapeutic target for personalized treatment of patients with NPC.

\section{RESULTS}

\section{MET protein expression in NPC}

MET protein expression was evaluated in 376 patients with locoregionally advanced nasopharyngeal carcinoma. Overall, the tumors of 74 (19.7\%), 163 (43.3\%), 104 (27.7\%) and $35(9.3 \%)$ patients had a MET immunohistochemical (IHC) staining score of $0,1+, 2+$ and $3+$, respectively (Figure 1A-1D). Overexpression of MET was observed in 37.0\% (139/376) of the NPC tissues. The groups of patients with high MET expression and low MET expression had similar distributions of host and tumor factors. In addition, there was no significant difference with regards to the radiotherapy (RT) technique or use of chemotherapy between groups. However, a lower frequency of WHO type IIb NPC was observed in patients with high MET expression compared to patients with low MET expression (90.6\% vs. $97.5 \%, P=0.004$; Table 1 ). Moreover, patients with high MET expression had a higher incidence of locoregional failure (25.2\% vs. $14.3 \%$, $P=0.009)$, distant metastasis $(28.8 \%$ vs. $16.9 \%, P=0.006)$ and death $(41.7 \%$ vs. $23.6 \%, P<0.001$; Table 1$)$.
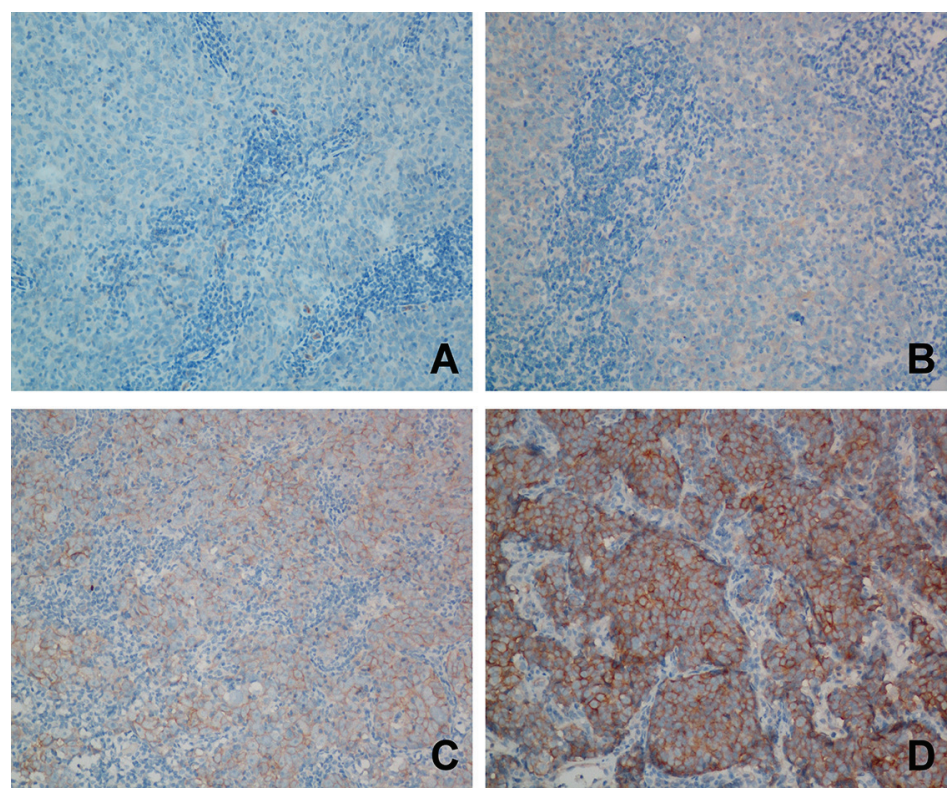

Figure 1: Representative images of immunohistochemical (IHC) staining for MET in locoregionally advanced nasopharyngeal carcinoma. A. MET IHC score of 0 . B. MET IHC score of $1+$. B. MET IHC score of 2+. C. MET IHC score of $3+$. 
Table 1: Association of MET protein expression and $M E T$ amplification status with the clinical characteristics of patients with locoregionally advanced nasopharyngeal carcinoma

\begin{tabular}{|c|c|c|c|c|c|c|}
\hline \multirow[t]{2}{*}{ Characteristic } & \multicolumn{2}{|c|}{ MET expression $(n=376)$} & \multirow[b]{2}{*}{$\boldsymbol{P}$} & \multicolumn{2}{|c|}{$M E T$ amplification $(n=139)$} & \multirow[b]{2}{*}{$\boldsymbol{P}$} \\
\hline & $\begin{array}{c}\text { Low } n(\%) \\
\quad(n=237)\end{array}$ & $\begin{array}{l}\text { High } n(\%) \\
\quad(n=139)\end{array}$ & & $\begin{array}{c}\text { Negative } n(\%), \\
(n=132)\end{array}$ & $\begin{array}{c}\text { Positive } n(\%) \\
(n=7)\end{array}$ & \\
\hline \multicolumn{7}{|l|}{ Age } \\
\hline$\leq 45$ years & $120(50.6)$ & $67(48.2)$ & 0.694 & $64(48.5)$ & $3(42.9)$ & 1.000 \\
\hline$>45$ years & $117(49.4)$ & $72(51.8)$ & & $68(51.5)$ & $4(51.1)$ & \\
\hline \multicolumn{7}{|l|}{ Gender } \\
\hline Male & $175(73.8)$ & $107(77.0)$ & 0.497 & $100(75.8)$ & $7(100.0)$ & 0.352 \\
\hline Female & $62(26.2)$ & $32(23.0)$ & & $32(24.2)$ & $0(0.0)$ & \\
\hline \multicolumn{7}{|l|}{ WHO Type } \\
\hline IIa & $6(2.5)$ & $13(9.4)$ & 0.004 & $13(9.8)$ & $0(0)$ & 1.000 \\
\hline IIb & $231(97.5)$ & $126(90.6)$ & & $119(90.2)$ & $7(100)$ & \\
\hline \multicolumn{7}{|l|}{ VCA-IgA } \\
\hline$<1: 80$ & $33(13.9)$ & $19(13.7)$ & 0.945 & $18(13.6)$ & $1(14.3)$ & 0.107 \\
\hline$\geq 1: 80$ & $204(86.1)$ & $120(86.3)$ & & $114(86.4)$ & $6(85.7)$ & \\
\hline \multicolumn{7}{|l|}{ EA-IgA } \\
\hline$<1: 10$ & $50(21.1)$ & $26(18.7)$ & 0.577 & $26(19.7)$ & $0(0)$ & 0.348 \\
\hline$\geq 1: 10$ & $187(78.9)$ & $113(81.3)$ & & $106(80.3)$ & $7(100)$ & \\
\hline \multicolumn{7}{|l|}{ T Stage } \\
\hline $\mathrm{T} 1-\mathrm{T} 2$ & $40(16.9)$ & $19(13.7)$ & 0.409 & $19(14.4)$ & $0(0)$ & 0.593 \\
\hline $\mathrm{T} 3-\mathrm{T} 4$ & $197(83.1)$ & $120(86.3)$ & & $113(85.6)$ & $7(100)$ & \\
\hline \multicolumn{7}{|l|}{ N Stage } \\
\hline N0-N1 & $125(52.7)$ & $84(60.4)$ & 0.147 & $80(60.6)$ & $4(57.1)$ & 1.000 \\
\hline N2-N3 & $112(47.3)$ & $55(39.6)$ & & $52(39.4)$ & $3(42.9)$ & \\
\hline \multicolumn{7}{|l|}{ TNM Stage } \\
\hline III & $134(56.5)$ & $79(56.8)$ & 0.956 & $75(56.8)$ & $4(57.1)$ & 1.000 \\
\hline IV & $103(43.5)$ & $60(43.2)$ & & $57(43.2)$ & $3(42.9)$ & \\
\hline \multicolumn{7}{|c|}{ Chemoradiotherapy } \\
\hline Yes & $197(83.1)$ & $114(82.0)$ & 0.784 & $107(81.1)$ & $7(100)$ & 0.351 \\
\hline No & $40(16.9)$ & $25(18.0)$ & & $25(18.9)$ & $0(0)$ & \\
\hline \multicolumn{7}{|l|}{ Radiotherapy } \\
\hline IMRT & $29(12.2)$ & $10(7.2)$ & 0.122 & $10(7.6)$ & $0(0)$ & 1.000 \\
\hline 2D-RT & $208(87.8)$ & $129(92.8)$ & & $122(92.4)$ & $7(100)$ & \\
\hline \multicolumn{7}{|c|}{ Locoregional failure } \\
\hline Yes & $34(14.3)$ & $35(25.2)$ & 0.009 & $33(25.0)$ & $2(28.6)$ & 1.000 \\
\hline No & $203(83.1)$ & $104(74.8)$ & & $99(75.0)$ & $5(71.4)$ & \\
\hline
\end{tabular}

(Continued) 


\begin{tabular}{|c|c|c|c|c|c|c|}
\hline \multirow[t]{2}{*}{ Characteristic } & \multicolumn{2}{|c|}{ MET expression $(n=376)$} & \multirow[b]{2}{*}{$P$} & \multicolumn{2}{|c|}{ MET amplification $(n=139)$} & \multirow[b]{2}{*}{$P$} \\
\hline & $\begin{array}{l}\text { Low } n(\%), \\
(n=237)\end{array}$ & $\begin{array}{l}\text { High } n(\%), \\
\quad(n=139)\end{array}$ & & $\begin{array}{l}\text { Negative } n(\%), \\
\quad(n=132)\end{array}$ & $\begin{array}{c}\text { Positive } n(\%) \\
\quad(n=7)\end{array}$ & \\
\hline \multicolumn{7}{|c|}{ Distant metastasis } \\
\hline Yes & $40(16.9)$ & $40(28.8)$ & 0.006 & $37(28.0)$ & $3(42.9)$ & 0.410 \\
\hline No & $197(85.6)$ & 99 (71.2) & & $95(72.0)$ & $4(57.1)$ & \\
\hline \multicolumn{7}{|l|}{ Death } \\
\hline Yes & $56(23.6)$ & $58(41.7)$ & $<0.001$ & $52(39.4)$ & $6(85.7)$ & 0.021 \\
\hline No & $181(76.4)$ & $81(58.3)$ & & $80(60.6)$ & $1(14.3)$ & \\
\hline
\end{tabular}

Abbreviations: WHO type IIa, differentiated non-keratinizing nasopharyngeal carcinoma; WHO type IIb, undifferentiated non-keratinizing nasopharyngeal carcinoma; VCA-IgA, viral capsid antigen immunoglobulin A; EA-IgA, early antigen immunoglobulin A; IMRT: intensity-modulated radiotherapy; 2D-RT: two-dimensional radiotherapy. All patients were restaged according to the $7^{\text {th }}$ edition of the AJCC Cancer Staging Manual.

\section{MET copy number status in patients with high MET expression}

The MET copy number status of the patients with high MET expression $(n=139)$ was analyzed using fluorescent in situ hybridization (FISH). In total, 7/139 (5.0\%) patients demonstrated MET amplification; 24 (17.3\%), 29 (20.9\%), $31(22.3 \%), 29(20.9 \%)$ and 19 $(13.7 \%)$ patients displayed high polysomy, low polysomy, high trisomy, low trisomy and disomy, respectively (Figure 2A-2F). The average $M E T$ copy number per tumor cell ranged from 1.6 to 9.67 (mean, 3.23). The MET/CEP7 ratio ranged from 0.9 to 4.1 (mean, 1.22).

The correlation between the MET amplification status and the clinicopathological characteristics of the patients with high MET expression are shown in Table 1. MET amplification was significantly associated with death $(85.7 \%$ vs. $39.4 \%, P=0.021)$. However, there was no significant association between the $M E T$ copy number status and any other clinicopathological factor.

\section{Correlation between $M E T$ copy number status and MET protein expression}

In the 139 patients with high MET expression, the MET copy number status correlated significantly with MET protein expression $(r=0.629, P<0.001$, Spearman's rank; Table 2). The cases with a MET IHC score of $3+$ had a markedly higher $M E T$ copy number compared to the cases with a MET IHC score of 2+. All seven tumors with MET amplification demonstrated a MET IHC score of $3+$, while no $M E T$ amplification was detected in the $2+$ tumors.

\section{Prognostic value of MET protein overexpression and $M E T$ amplification}

Univariate analysis indicated that MET protein expression, TNM stage, gender and WHO type had a significant impact on 5-year overall survival (OS) and disease-free survival (DFS; both $P<0.05$; Table 3). The 5 -year OS (58.6\% vs. 76.9\%, $P<0.001$; Figure $3 \mathrm{~A})$ and DFS (48.5\% vs. $68.8 \%, P<0.001$; Figure $3 \mathrm{~B}$ ) rates for patients with high MET expression were significantly lower than the corresponding rates for patients with low MET expression. In the group of patients with high MET expression, $M E T$ gene amplification was associated with poorer OS and DFS $(P<0.05)$ in univariate analysis, and patients with $M E T$ amplification had significantly poorer 5 -year OS (48.5\% vs. $68.8 \%, P<0.001$; Figure $3 \mathrm{C})$ and DFS ( $0.0 \%$ vs. $51.1 \%, P<0.001$; Figure 3D).

Multivariate analysis revealed MET protein overexpression was an independent prognostic factor for OS (HR, 1.99; 95\% CI, 1.38-2.87; $P<0.001$ ) and DFS (HR, $1.85 ; 95 \% \mathrm{CI}, 1.33-2.57 ; P<0.001)$. TNM stage and gender were also found to be independent prognostic factors for OS and DFS (Table 3). Moreover, in the group of patients with high MET expression, MET amplification was also an independent prognostic factor for OS (HR, 4.24; 95\% CI, $1.78-10.08 ; P<0.001)$ and DFS (HR, 5.44; 95\% CI, 2.44$12.09 ; P<0.001)$. Taken together, these results indicate that MET protein overexpression is associated with unfavorable OS and DFS, and that MET amplification can be used to identify a subgroup of patients with high MET expression at risk of poor survival outcomes.

\section{DISCUSSION}

In the present study, we report that MET protein was overexpressed in the tumors of $37.0 \%$ of the patients with locoregionally advanced NPC, with MET gene amplification observed in $5.0 \%$ of the patients with high MET expression. MET overexpression and MET amplification were both associated with a significantly poorer prognosis and were identified as independent prognostic factors for overall survival (OS) and diseasefree survival (DFS). These results suggest that MET 

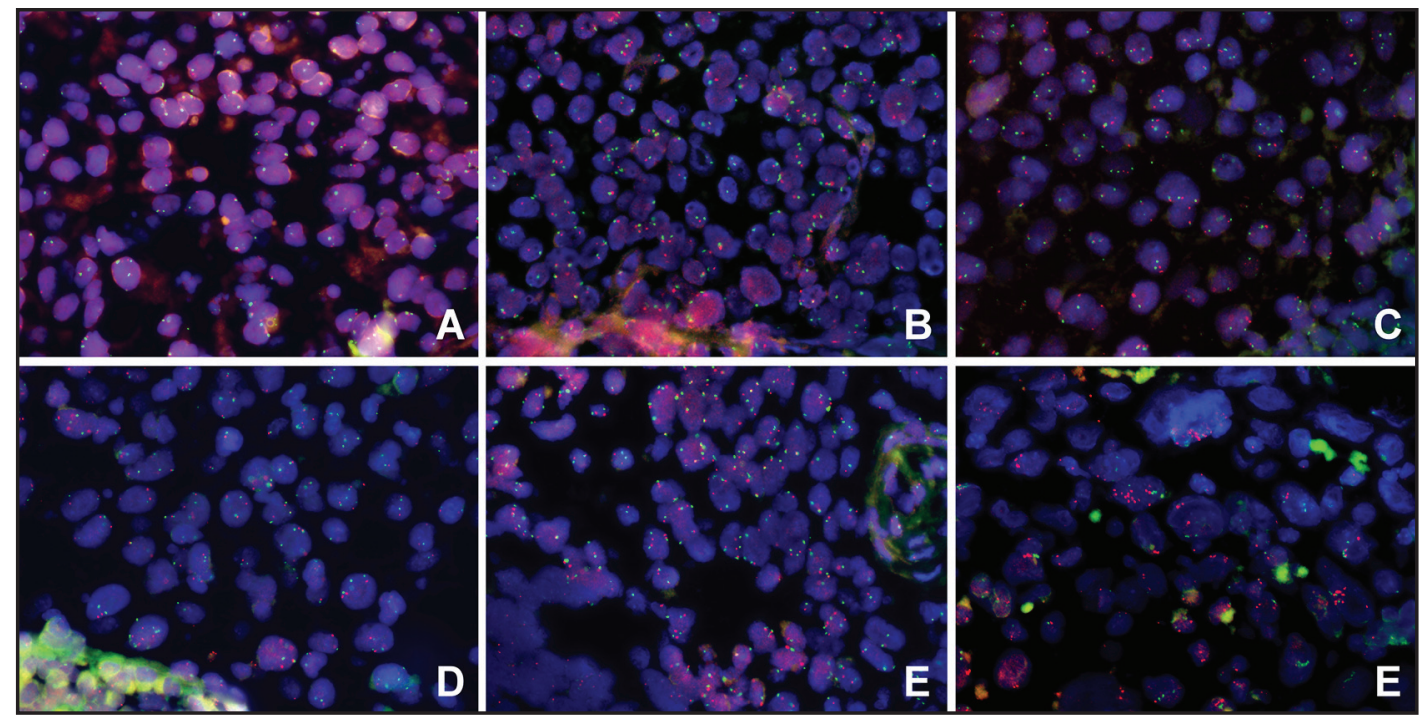

Figure 2: Evaluation of MET gene copy number status in patients with high MET expression in locoregionally advanced nasopharyngeal carcinoma using FISH. A-F. Representative images of tumors with MET disomy A. low trisomy B. high trisomy $\mathbf{C}$. low polysomy $\mathbf{D}$. high polysomy $\mathbf{E}$. and $M E T$ amplification $\mathbf{F}$.

Table 2: Correlation between $M E T$ copy number status and MET protein expression in the
139 patients with high MET expression

\begin{tabular}{|c|c|c|c|c|c|c|c|}
\hline \multirow[b]{2}{*}{ IHC Score } & \multicolumn{6}{|c|}{$M E T$ copy number status } & \multirow[b]{2}{*}{ Total } \\
\hline & $\begin{array}{c}\text { Disomy } \\
n(\%)\end{array}$ & $\begin{array}{c}\text { Low Trisomy } \\
n(\%)\end{array}$ & $\begin{array}{c}\text { High } \\
\text { Trisomy } \\
n(\%)\end{array}$ & $\begin{array}{c}\text { Low } \\
\text { Polysomy } \\
n(\%)\end{array}$ & $\begin{array}{c}\text { High } \\
\text { Polysomy } \\
n(\%)\end{array}$ & $\begin{array}{c}\text { Amplification } \\
n(\%)\end{array}$ & \\
\hline $2+$ & $19(100)$ & 28 (96.6) & $30(96.8)$ & $20(69.0)$ & $7(29.2)$ & $0(0)$ & 104 \\
\hline $3+$ & $0(0)$ & $1(3.4)$ & $1(3.2)$ & $9(31.0)$ & $17(70.8)$ & $7(100)$ & 35 \\
\hline Total & 19 & 29 & 31 & 29 & 24 & 7 & 139 \\
\hline
\end{tabular}

Abbreviation: IHC, immunohistochemistry score.

overexpression and $M E T$ amplification are potential biomarkers that could enable identification of a subgroup of patients with NPC who may be sensitive to METtargeted therapy.

MET is aberrantly activated in a wide range of tumors, including lung cancer, gastric cancer, glioblastoma and renal-cell carcinoma [19, 22, 31, 32]. Aberrant MET signaling contributes to the initiation and progression of cancer [11, 12, 14, 16]. Accumulating evidence indicates that protein overexpression is one of the major mechanisms underlying the aberrant activation of MET, and overexpression of MET is associated with poor patient survival in a variety of types of cancer [25, 33-35]. Although several studies have evaluated the frequency and prognostic value of MET overexpression in NPC, the results of these studies are highly variable, with MET overexpression rates ranging from $51.5 \%$ to $91.1 \%$, and some studies even reporting that MET had no significant prognostic value [28-30]. These controversial results may stem from the analysis of relatively small cohorts, as well as the use of different primary and secondary antibodies, staining protocols and scoring criteria. With the progression of MET inhibitors into clinical trials, an IHC assay was developed to evaluate MET protein expression using a rabbit monoclonal antibody SP44 [36]. During Phase II studies in gastric cancer (rilotumumab) and non-small cell lung cancer (onartuzumab), an IHC scoring algorithm based on the proportion of positive tumor cells and the staining intensity was established [36-39]. Using these IHC methods, antibody and scoring system, patients whose tumors overexpressed MET were demonstrated to benefit from MET-targeted therapies [36-39]. Using the same protocol, we identified that 37.0\% of patients with locally advanced NPC overexpressed MET protein. Additionally, significant associations were observed between MET overexpression and locoregional failure, distant metastasis and death in patients with locoregionally advanced NPC, consistent with previous observations in gastric and lung cancer [25, 33-35]. Furthermore, overexpression of MET was associated 
Table 3: Univariate and multivariable Cox regression analysis of prognostic factors in 376 patients with locoregionally advanced NPC

\begin{tabular}{|c|c|c|c|c|c|c|}
\hline \multirow[t]{2}{*}{ Variable } & \multicolumn{3}{|c|}{ Univariate analysis } & \multicolumn{3}{|c|}{ Multivariate analysis } \\
\hline & HR & $95 \% \mathrm{CI}$ & $P$-value & HR & $95 \% \mathrm{CI}$ & $P$-value \\
\hline \multicolumn{7}{|l|}{ Overall survival } \\
\hline $\begin{array}{l}\text { MET expression } \\
\text { (High vs. low) }\end{array}$ & 1.98 & $1.37-2.87$ & $<0.001$ & 1.99 & $1.38-2.87$ & $<0.001$ \\
\hline $\begin{array}{l}\text { TNM stage } \\
\text { (IV vs. III) }\end{array}$ & 1.91 & $1.32-2.77$ & 0.001 & 1.93 & $1.33-2.79$ & 0.001 \\
\hline $\begin{array}{l}\text { Gender } \\
\text { (Male vs. female) }\end{array}$ & 2.05 & $1.23-3.44$ & 0.006 & 1.99 & $1.19-3.33$ & 0.009 \\
\hline $\begin{array}{l}\text { Age }(\geq 45 \text { vs. }<45 \\
\text { years })\end{array}$ & 1.58 & $1.08-2.29$ & 0.02 & 1.50 & $1.03-2.18$ & 0.035 \\
\hline $\begin{array}{l}\text { WHO type } \\
\text { (IIb vs. IIa) }\end{array}$ & 0.49 & $0.26-0.94$ & 0.03 & & & NS \\
\hline $\begin{array}{l}\text { VCA IgA } \\
(\geq 1: 80 \text { vs. }<1: 80)\end{array}$ & 0.76 & $0.47-1.25$ & 0.28 & & & \\
\hline $\begin{array}{l}\text { EA IgA } \\
(\geq 1: 10 \text { vs. }<1: 10)\end{array}$ & 0.82 & $0.53-1.27$ & 0.37 & & & \\
\hline $\begin{array}{l}\text { Chemotherapy } \\
\text { (No vs. yes) }\end{array}$ & 1.00 & $0.62-1.63$ & 0.97 & & & \\
\hline $\begin{array}{l}\text { Radiotherapy } \\
\text { (2D-RT vs. IMRT) }\end{array}$ & 1.06 & $0.58-1.92$ & 0.86 & & & \\
\hline \multicolumn{7}{|l|}{ Disease-free survival } \\
\hline $\begin{array}{l}\text { MET expression } \\
\text { (High vs. low) }\end{array}$ & 1.95 & $1.41-2.70$ & $<0.001$ & 1.85 & $1.33-2.57$ & $<0.001$ \\
\hline $\begin{array}{l}\text { TNM stage } \\
\text { (IV vs. III) }\end{array}$ & 1.69 & $1.22-2.33$ & 0.002 & 1.71 & $1.24-2.36$ & 0.001 \\
\hline $\begin{array}{l}\text { Gender } \\
\text { (Male vs. female) }\end{array}$ & 1.55 & $1.03-2.32$ & 0.04 & 1.52 & $1.02-2.29$ & 0.042 \\
\hline $\begin{array}{l}\text { WHO type } \\
\text { (IIb vs. IIa) }\end{array}$ & 0.42 & $0.24-0.75$ & 0.003 & 0.54 & $0.30-0.97$ & 0.039 \\
\hline $\begin{array}{l}\text { Age } \\
(\geq 45 \text { vs. }<45 \text { years })\end{array}$ & 1.25 & $0.91-1.73$ & 0.17 & & & \\
\hline $\begin{array}{l}\text { VCA IgA } \\
(\geq 1: 80 \text { vs. }<1: 80)\end{array}$ & 0.87 & $0.56-1.37$ & 0.56 & & & \\
\hline $\begin{array}{l}\text { EA IgA } \\
(\geq 1: 10 \text { vs. }<1: 10)\end{array}$ & 0.96 & $0.64-1.42$ & 0.82 & & & \\
\hline $\begin{array}{l}\text { Chemotherapy (No } \\
\text { vs. yes) }\end{array}$ & 1.12 & $0.74-1.69$ & 0.59 & & & \\
\hline $\begin{array}{l}\text { Radiotherapy } \\
\text { (2D-RT vs. IMRT) }\end{array}$ & 1.13 & $0.65-1.97$ & 0.66 & & & \\
\hline
\end{tabular}

Abbreviations: WHO type IIa, differentiated non-keratinizing nasopharyngeal carcinoma; WHO type IIb, undifferentiated non-keratinizing nasopharyngeal carcinoma; VCA-IgA, viral capsid antigen immunoglobulin A; EA-IgA, early antigen immunoglobulin A; IMRT: intensity-modulated radiotherapy; 2D-RT: two-dimensional radiotherapy; HR, hazard ratio; NS, not significant. 

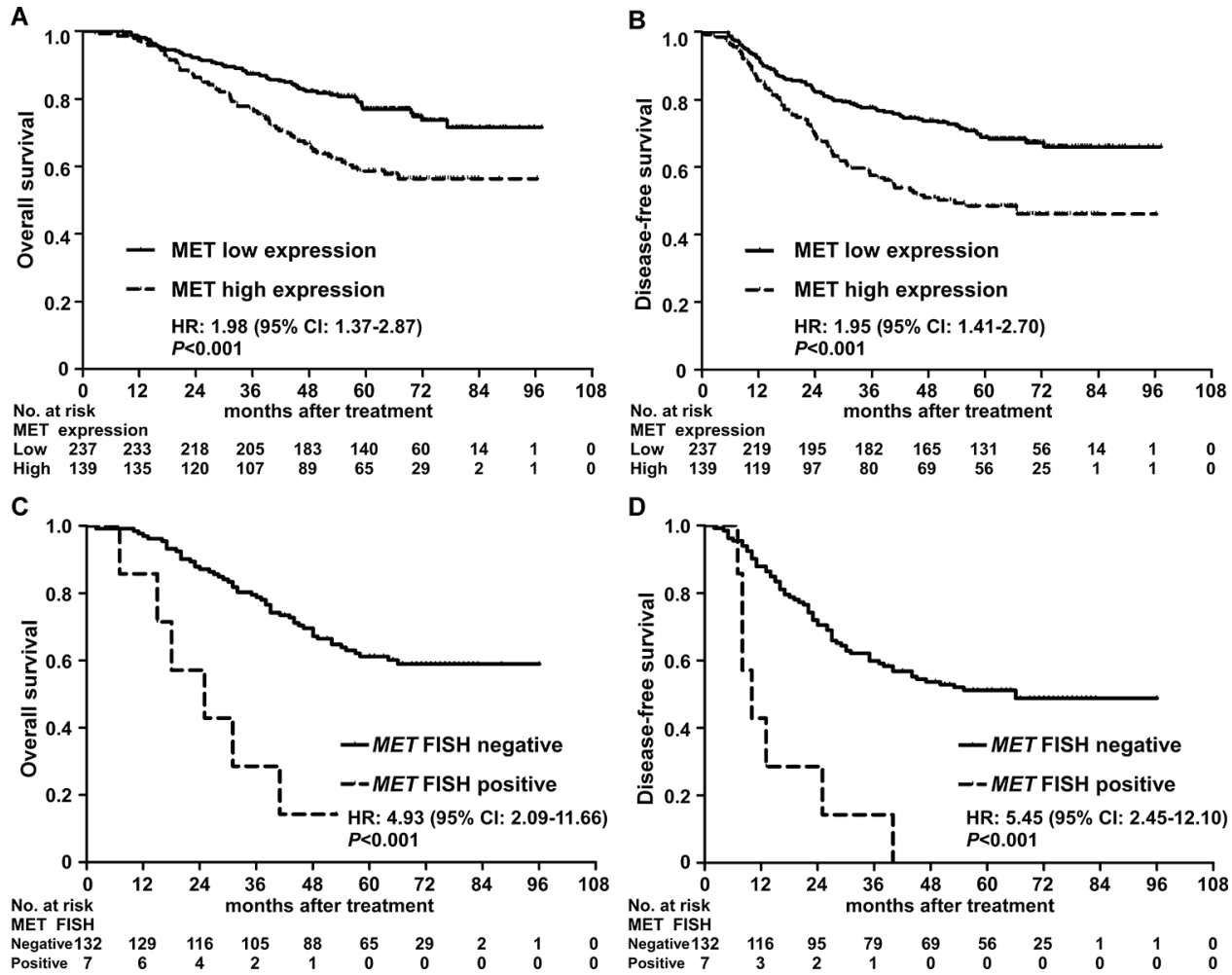

Figure 3: Kaplan-Meier overall survival and disease-free survival curves for patients with nasopharyngeal carcinoma stratified by MET protein expression and MET amplification status. A-B. Overall survival and disease-free survival curves for patients stratified by MET protein expression. C-D. Overall survival and disease-free survival curves for patients with high MET expression stratified by MET amplification status. Hazard ratios (HRs) were calculated using the unadjusted Cox proportional hazards model; $P$-values were calculated using the unadjusted log-rank test. CI, confidence interval.

with significantly poorer survival outcomes, suggesting that identification of MET overexpression using IHC may provide a potential biomarker to enable the individualized treatment of patients with NPC.

Gene amplification is another well-recognized mechanism that can lead to constitutive activation of MET [19, 40]. Based on the gold standard method of FISH, several studies have reported that $M E T$ is amplified in $\sim 5 \%$ patients with non-small cell lung cancer and gastric cancer [19, 22, 34, 35, 41]. Additionally, patients with $M E T$ amplification have a poorer clinical prognosis $[22,42,43]$. Interestingly, MET protein overexpression correlated significantly with $M E T$ amplification, and MET amplification was rare in patients with low MET expression, ranging from $0 \%(0 / 283)$ to $0.6 \%(1 / 163)$ $[34,35]$. Preliminary data from other studies have suggested that $M E T$ amplification can identify subgroups of patients with lung or gastric cancer who may benefit from MET inhibitors, suggesting that MET amplification as a may represent a putative biomarker [20, 27, 44, 45]. However, until now, the prevalence of $M E T$ amplification was unknown in NPC. This study demonstrated that $5.0 \%$ of patients with high MET expression had MET amplification. A significantly positive correlation was observed between MET amplification and MET protein overexpression, in agreement with previous data in gastric and lung cancer [35, 42]. All patients with $M E T$ amplification had a MET IHC score of $3+$, and the majority of the remaining patients with a MET IHC score of $3+$ had polysomy. Moreover, MET amplification was an independent prognostic factor for OS and DFS, further indicating that $M E T$ amplification may identify a subgroup of patients with high MET expression at risk of poorer survival who may benefit from MET inhibitor therapy.

In conclusion, this study evaluated the frequency of MET overexpression and MET amplification in locoregionally advanced NPC, and demonstrated that both MET overexpression and MET amplification were associated with poorer OS and DFS. These results enhance our knowledge of the mechanisms underlying aberrant activation of the MET pathway in NPC, and may help to establish MET as a novel prognostic biomarker and therapeutic target for the treatment of subgroups of patients with locoregionally advanced NPC.

\section{MATERIALS AND METHODS}

\section{Clinical specimens}

Paraffin-embedded biopsy specimens from 376 consecutive patients with histologically-confirmed, nondistant metastatic NPC treated at Sun Yat-sen University 
Cancer Center between January 2006 and December 2009 were evaluated; all samples were pathologically confirmed by two pathologists. No patients received radiotherapy or chemotherapy before biopsy. All MRI/CT materials and clinical records were reviewed and patients were restaged according to the 7th edition of the AJCC Cancer Staging Manual. The clinical characteristics of the patients are summarized in Table 1. Written informed consent was obtained from all patients. This study was approved by the Institutional Ethical Review Board of Sun Yat-sen University Cancer Center.

\section{Patient treatment and follow-up}

All patients received radiotherapy, as previously described [6]; 337 patients (89.6\%) were treated with conventional two-dimensional radiotherapy (2D-RT) and $39(10.4 \%)$ with intensity-modulated radiotherapy (IMRT). All patients had stage III $(56.6 \%)$ or IV (43.4\%) NPC. A total of 311 patients $(82.7 \%)$ received concurrent platinum-based chemotherapy with or without neoadjuvant/adjuvant chemotherapy, as previously described $[4,5]$. Concurrent chemotherapy consisted of cisplatin administered on weeks 1, 4 and 7 of radiotherapy, or weekly. Neoadjuvant and adjuvant chemotherapy consisted of cisplatin with 5-flurouracil or taxanes every three weeks for three cycles.

\section{Follow-up}

All patients were followed-up at least every 3 months during the first 2 years and then every 6 months thereafter until death. Median follow-up was 62.4 months (range, 2.6-97.3 months). The following end points were assessed: overall survival (OS) and disease-free survival (DFS). OS was calculated from the first day of treatment to death; DFS, from the first day of treatment to disease progression or death from any cause.

\section{Immunohistochemistry}

Immunohistochemistry (IHC) for MET was performed using an automatic staining system (Bench Mark ULTRA; Ventana Medical Systems, Tucson, AZ, USA), according to the manufacturer's instructions with CONFIRM anti-total MET antibody (SP44; rabbit monoclonal primary antibody; Ventana Medical Systems). Immunostaining was evaluated on the basis of the staining intensity (negative, weak, moderate, strong) and the percentage of cells stained, according to the MET IHC scoring criteria for non-small cell lung cancer [36, 37]. The MET IHC scores ranged from 0 to $3+$ as follows: 0 (no staining or $<50 \%$ of tumor cells with any intensity); $1+$ ( $\geq 50 \%$ of tumor cells with weak or higher staining intensity and $<50 \%$ with moderate or higher intensity); $2+(\geq 50 \%$ of tumor cells with moderate or higher staining intensity and $<50 \%$ strong intensity); $3+(\geq 50 \%$ of tumor cells with strong staining intensity). Scores of $2+$ and $3+$ were defined as high MET expression, scores of $1+$ and 0 were defined as low MET expression. The IHC scores were independently evaluated by two pathologists who were blinded to the clinical and molecular characteristics of the patients.

\section{Fluorescence in situ hybridization}

MET copy number was evaluated using fluorescence in situ hybridization (FISH), as previously described [46]. Briefly, $4 \mu \mathrm{m}$ tissue sections were hybridized overnight with the Vysis MET Spectrum Red FISH Probe (Abbott Molecular, Chicago, IL, USA) and control Vysis CEP7 centromere Spectrum Green Probe (Abbott Molecular). The entire area of each section was scanned using a $100 \times$ objective (Olympus, Tokyo, Japan) and appropriate filter sets (Vysis; Abbott Molecular). The MET (red) and CEP7 (green) signals were evaluated for at least 100 nonoverlapping nuclei in each slide.

Patients were classified into six groups based on the MET copy number status, according to the University of Colorado Cancer Center criteria [46]: 1, disomy ( $<90 \%$ of tumor cells containing $\leq 2$ MET signals); 2 , low trisomy $(\geq 40 \%$ of tumor cells containing $\leq 2$ MET signals, $10-40 \%$ of tumor cells containing three MET signals, and $<10 \%$ of tumor cells containing $\geq$ 4 MET signals); 3 , high trisomy ( $\geq 40 \%$ of tumor cells containing $\leq 2$ MET signals, and $\geq 40 \%$ of tumor cells containing three MET signals, and $<10 \%$ of tumor cells containing $\geq 4$ MET signals); 4 , low polysomy (10-40\% of tumor cells containing $\geq 4$ MET signals); 5 , high polysomy ( $\geq 40 \%$ of tumor cells containing $\geq$ 4 MET signals) and 6, MET amplification (MET/CEP7 ratio $\geq 2.0$ or $\geq 10 \%$ of tumor cells containing $\geq 15 \mathrm{MET}$ signals). MET amplification was defined as MET FISHpositive; the remaining cases were classified as $M E T$ FISH-negative. MET copy number status was determined by two investigators while blinded to the clinical and molecular characteristics of the patients and IHC data.

\section{Statistical analysis}

All statistical analysis was performed using SPSS 16.0 software (IBM, Armonk, NY, USA). Categorical variables were compared using the $\chi^{2}$ and Fisher's exact tests. The association between MET FISH status and MET protein expression was evaluated using the Spearman's rank method. Actuarial rates were calculated using the KaplanMeier method; differences were compared using the logrank test. Multivariate analysis using a Cox proportional hazards model was performed to calculate hazard ratios (HRs) and 95\% confidence intervals (CIs), and assess independent significance by backward elimination of insignificant explanatory variables. Covariates including host factors (i.e., age and gender), tumor factors (i.e., WHO type, clinical stage, $\mathrm{T}$ and $\mathrm{N}$ classification), radiotherapy (RT) technique and chemotherapeutic intervention 
(i.e., RT alone or chemo-RT) were included in all tests. All tests were two-tailed; $P$-values $<0.05$ were considered statistically significant.

\section{CONFLICTS OF INTEREST}

The authors declare no conflict of interest.

\section{GRANT SUPPORT}

This work was supported by grants from the National Natural Science Foundation of China (81402516), the Pearl River Science and Technology New Star of Guangzhou, China (2015), the Health \& Medical Collaborative Innovation Project of Guangzhou City, China (201400000001), the National Science \& Technology Pillar Program during the Twelfth Five-year Plan Period (2014BAI09B10), the Science and Technology Project of Guangzhou City, China (No.14570006), the Planned Science and Technology Project of Guangdong Province (No. 2013B020400004), and the Key Laboratory Construction Project of Guangzhou City, China (No.121800085).

\section{REFERENCES}

1. Jemal A, Bray F, Center MM, Ferlay J, Ward E, Forman D. Global cancer statistics. CA Cancer J Clin. 2011; 61:69-90.

2. McDermott AL, Dutt SN, Watkinson JC. The aetiology of nasopharyngeal carcinoma. Clin Otolaryngol Allied Sci. 2001; 26:82-92.

3. Wei WI, Sham JS. Nasopharyngeal carcinoma. Lancet 2005; 365:2041-2054.

4. Lee AW, Lin JC, Ng WT. Current management of nasopharyngeal cancer. Semin Radiat Oncol. 2012; 22:233-244.

5. Baujat B, Audry H, Bourhis J, Chan AT, Onat H, Chua DT, Kwong DL, Al-Sarraf M, Chi KH, Hareyama M, Leung SF, Thephamongkhol K, Pignon JP, et al. Chemotherapy in locally advanced nasopharyngeal carcinoma: an individual patient data meta-analysis of eight randomized trials and 1753 patients. Int J Radiat Oncol Biol Phys. 2006; 64:47-56.

6. Lai SZ, Li WF, Chen L, Luo W, Chen YY, Liu LZ, Sun Y, Lin AH, Liu MZ, Ma J. How does intensity-modulated radiotherapy versus conventional two-dimensional radiotherapy influence the treatment results in nasopharyngeal carcinoma patients? Int J Radiat Oncol Biol Phys. 2011; 80:661-668.

7. Chen YP, Wang ZX, Chen L, Liu X, Tang LL, Mao YP, Li WF, Lin AH, Sun Y, Ma J. A Bayesian network metaanalysis comparing concurrent chemoradiotherapy followed by adjuvant chemotherapy, concurrent chemoradiotherapy alone and radiotherapy alone in patients with locoregionally advanced nasopharyngeal carcinoma. Ann Oncol. 2014; 26:205-211.
8. Mok TS, Wu YL, Thongprasert S, Yang CH, ChuDT, Saijo N, Sunpaweravong P, Han B, Margono B, Ichinose Y, Nishiwaki Y, Ohe Y, Yang JJ, et al. Gefitinib or carboplatin-paclitaxel in pulmonary adenocarcinoma. N Engl J Med. 2009; 361:947-957.

9. Sequist LV, Martins RG, Spigel D, Grunberg SM, Spira A, Janne PA, Joshi VA, McCollum D, Evans TL, Muzikansky A, Kuhlmann GL, Han M, Goldberg JS, et al. First-line gefitinib in patients with advanced non-smallcell lung cancer harboring somatic EGFR mutations. J Clin Oncol. 2008; 26:2442-2449.

10. Wang X, DeFrances MC, Dai Y, Pediaditakis P, Johnson C, Bell A, Michalopoulos GK, Zarnegar R. A mechanism of cell survival: sequestration of Fas by the HGF receptor Met. Mol Cell. 2002; 9:411-421.

11. Giordano S, Ponzetto C, Di Renzo MF, Cooper CS, Comoglio PM. Tyrosine kinase receptor indistinguishable from the c-met protein. Nature. 1989; 339:155-156.

12. Trusolino L, Bertotti A, Comoglio PM. MET signalling: principles and functions in development, organ regeneration and cancer. Nat Rev Mol Cell Biol. 2010; 11:834-848.

13. Liu P, Cheng H, Santiago S, Raeder M, Zhang F, Isabella A, Yang J, Semaan DJ, Chen C, Fox EA, Gray NS, Monahan J, Schlegel R, et al. Oncogenic PIK3CA-driven mammary tumors frequently recur via PI3K pathway-dependent and PI3K pathway-independent mechanisms. Nat Med. 2011; 17:1116-1120.

14. Joffre C, Barrow R, Menard L, Calleja V, Hart IR, Kermorgant S. A direct role for Met endocytosis in tumorigenesis. Nat Cell Biol. 2011; 13:827-837.

15. Maina F, Pante G, Helmbacher F, Andres R, Porthin A, Davies AM, Ponzetto C, Klein R. Coupling Met to specific pathways results in distinct developmental outcomes. Mol Cell. 2001; 7:1293-1306.

16. Birchmeier C, Birchmeier W, Gherardi E, Vande WG. Met, metastasis, motility and more. Nat Rev Mol Cell Biol. 2003; 4:915-925.

17. Gherardi E, Birchmeier W, Birchmeier C, Vande WG. Targeting MET in cancer: rationale and progress. Nat Rev Cancer. 2012; 12:89-103.

18. Kentsis A, Reed C, Rice KL, Sanda T, Rodig SJ, Tholouli E, Christie A, Valk PJ, Delwel R, Ngo V, Kutok JL, Dahlberg SE, Moreau LA, et al. Autocrine activation of the MET receptor tyrosine kinase in acute myeloid leukemia. Nat Med. 2012; 18:1118-1122.

19. Graziano F, Galluccio N, Lorenzini P, Ruzzo A, Canestrari E, D'Emidio S, Catalano V, Sisti V, Ligorio C, Andreoni F, Rulli E, Di Oto E, Fiorentini G, et al. Genetic activation of the MET pathway and prognosis of patients with high-risk, radically resected gastric cancer. J Clin Oncol. 2011; 29:4789-4795.

20. Lennerz JK, Kwak EL, Ackerman A, Michael M, Fox SB, Bergethon K, Lauwers GY, Christensen JG, Wilner KD, Haber DA, Salgia R, Bang YJ, Clark JW, 
et al. MET amplification identifies a small and aggressive subgroup of esophagogastric adenocarcinoma with evidence of responsiveness to crizotinib. J Clin Oncol. 2011; 29:4803-4810.

21. Saada E, Peoc'H M, Decouvelaere AV, Collard O, Peyron AC, Pedeutour F. CCND1 and MET genomic amplification during malignant transformation of a giant cell tumor of bone. J Clin Oncol. 2011; 29:e86-e89.

22. Cappuzzo F, Marchetti A, Skokan M, Rossi E, Gajapathy S, Felicioni L, Del GM, Sciarrotta MG, Buttitta F, Incarbone M, Toschi L, Finocchiaro G, Destro A, et al. Increased MET gene copy number negatively affects survival of surgically resected non-small-cell lung cancer patients. J Clin Oncol. 2009; 27:1667-1674.

23. Peters S, Adjei AA. MET: a promising anticancer therapeutic target. Nat Rev Clin Oncol. 2012; 9:314-326.

24. Comoglio PM, Giordano S, Trusolino L. Drug development of MET inhibitors: targeting oncogene addiction and expedience. Nat Rev Drug Discov. 2008; 7:504-516.

25. Blumenschein GJ, Mills GB, Gonzalez-Angulo AM. Targeting the hepatocyte growth factor-cMET axis in cancer therapy. J Clin Oncol. 2012; 30:3287-3296.

26. Appleman LJ. MET signaling pathway: a rational target for cancer therapy. J Clin Oncol. 2011; 29:4837-4838.

27. Smolen GA, Sordella R, Muir B, Mohapatra G, Barmettler A, Archibald H, Kim WJ, Okimoto RA, Bell DW, Sgroi DC, Christensen JG, Settleman J, Haber DA. Amplification of MET may identify a subset of cancers with extreme sensitivity to the selective tyrosine kinase inhibitor PHA-665752. Proc Natl Acad Sci USA. 2006; 103:2316-2321.

28. Li Z, Lin SX, Liang HZ, He JH. Expression of hepatocyte growth factor/c-Met system in nasopharyngeal carcinoma and its biological significance. Zhonghua Bing Li Xue Za Zhi. 2005; 34:75-79.

29. Qian CN, Guo X, Cao B, Kort EJ, Lee CC, Chen J, Wang LM, Mai WY, Min HQ, Hong MH, Vande WG, Resau JH, Teh BT. Met protein expression level correlates with survival in patients with late-stage nasopharyngeal carcinoma. Cancer Res. 2002; 62:589-596.

30. Xie LQ, Bian LJ, Li Z, Li Y, Li ZX, Li B. Altered expression of E-cadherin by hepatocyte growth factor and effect on the prognosis of nasopharyngeal carcinoma. Ann Surg Oncol. 2010; 17:1927-1936.

31. Sadiq AA, Salgia R. MET as a possible target for nonsmall-cell lung cancer. J Clin Oncol. 2013; 31:1089-1096.

32. Snuderl M, Fazlollahi L, Le LP, Nitta M, Zhelyazkova BH, Davidson CJ, Akhavanfard S, Cahill DP, Aldape KD, Betensky RA, Louis DN, Iafrate AJ. Mosaic amplification of multiple receptor tyrosine kinase genes in glioblastoma. Cancer Cell. 2011; 20:810-817.

33. Yu S, Yu Y, Zhao N, Cui J, Li W, Liu T. C-Met as a prognostic marker in gastric cancer: a systematic review and meta-analysis. PLoS One. 2013; 8:e79137.
34. Lee HE, Kim MA, Lee HS, Jung EJ, Yang HK, Lee BL, Bang YJ, Kim WH. MET in gastric carcinomas: comparison between protein expression and gene copy number and impact on clinical outcome. Br J Cancer. 2012; 107:325-333.

35. An X, Wang F, Shao Q, Wang F, Wang Z, Chen C, Li C, Luo H, Zhang D, Xu R, Li Y. MET Amplification Is Not Rare and Predicts Unfavorable Clinical Outcomes in Patients With Recurrent $=$ Metastatic Gastric Cancer After Chemotherapy. Cancer. 2014; 120:675-682.

36. Koeppen H, Rost S, Yauch RL. Developing biomarkers to predict benefit from HGF/MET pathway inhibitors. J Pathol. 2014; 232:210-218.

37. Spigel DR, Ervin TJ, Ramlau RA, Daniel DB, Goldschmidt JJ, Blumenschein GJ, Krzakowski MJ, Robinet G, Godbert B, Barlesi F, Govindan R, Patel T, Orlov SV, et al. Randomized phase II trial of Onartuzumab in combination with erlotinib in patients with advanced nonsmall-cell lung cancer. J Clin Oncol. 2013; 31:4105-4114.

38. Iveson $\mathrm{T}$, Donehower RC, Davidenko I, Tjulandin S, Deptala A, Harrison M, Nirni S, Lakshmaiah K, Thomas A, Jiang Y, Zhu M, Tang R, Anderson A, et al. Rilotumumab in combination with epirubicin, cisplatin, and capecitabine as first-line treatment for gastric or oesophagogastric junction adenocarcinoma: an open-label, dose de-escalation phase $1 \mathrm{~b}$ study and a double-blind, randomised phase 2 study. Lancet Oncol. 2014; 15:1007-1018.

39. Spigel DR, Edelman MJ, Mok T, O’Byrne K, Paz-Ares L, Yu W, Rittweger K, Thurm H. Treatment Rationale Study Design for the Met Lung Trial: A Randomized, DoubleBlind Phase III Study of Onartuzumab (MetMAb) in Combination With Erlotinib Versus Erlotinib Alone in Patients Who Have Received Standard Chemotherapy for Stage IIIB or IV Met-Positive Non-Small-Cell Lung Cancer. Clin Lung Cancer. 2012; 13:500-504.

40. Hellman A, Zlotorynski E, Scherer SW, Cheung J, Vincent JB, Smith DI, Trakhtenbrot L, Kerem B. A role for common fragile site induction in amplification of human oncogenes. Cancer Cell. 2002; 1:89-97.

41. Jardim DLF, Tang C, Gagliato DDM, Falchook GS, Hess K, Janku F, Fu S, Wheler JJ, Zinner RG, Naing A, Tsimberidou AM, Holla V, Li MM, et al. Analysis of 1,115 Patients Tested for MET Amplification and Therapy Response in the MD Anderson Phase I Clinic. Clin Cancer Res. 2014; 20:6336-6345.

42. Schildhaus HU, Schultheis AM, Ruschoff J, Binot E, Merkelbach-Bruse S, Fassunke J, Schulte W, Ko YD, Schlesinger A, Bos M, Gardizi M, Engel-Riedel W, Brockmann M, et al. MET Amplification Status in TherapyNaive Adeno- and Squamous Cell Carcinomas of the Lung. Clin Cancer Res. 2014; . DOI: 10.1158/1078-0432.

43. Jin Y, Sun P, Kim H, Seo AN, Jheon S, Lee C, Chung J. MET Gene Copy Number Gain is an Independent Poor Prognostic Marker in Korean Stage I Lung Adenocarcinomas. Ann Surg Oncol. 2014; 21:621-628. 
44. Koeppen H, Yu W, Zha J, Pandita A, Penuel E, Rangell L, Raja R, Mohan S, Patel R, Desai R, Fu L, Do A, Parab V, et al. Biomarker Analyses from a Placebo-Controlled Phase II Study Evaluating Erlotinib \pm Onartuzumab in Advanced Non-Small Cell Lung Cancer: MET Expression Levels Are Predictive of Patient Benefit. Clin Cancer Res. 2014; 20:4488-4498.

45. Choueiri TK, Vaishampayan U, Rosenberg JE, Logan TF, Harzstark AL, Bukowski RM, Rini BI, Srinivas S, Stein MN, Adams LM, Ottesen LH, Laubscher KH,
Sherman L, et al. Phase II and biomarker study of the dual MET/VEGFR2 inhibitor foretinib in patients with papillary renal cell carcinoma. J Clin Oncol. 2013; 31:181-186.

46. Cappuzzo F, Hirsch FR, Rossi E, Bartolini S, Ceresoli GL, Bemis L, Haney J, Witta S, Danenberg K, Domenichini I, Ludovini V, Magrini E, Gregorc V, et al. Epidermal growth factor receptor gene and protein and gefitinib sensitivity in non-small-cell lung cancer. J Natl Cancer Inst. 2005; 97:643-655. 